\title{
PERKEMBANGAN PEMBANGUNAN BERKELANJUTAN DILIHAT DARI ASPEK EKONOMI DI INDONESIA
}

\author{
Nur Arief Hapsoro ${ }^{1}$, Kresensia Bangun ${ }^{2}$ \\ ${ }^{1}$ Universitas Telkom, Program Studi Desain Interior \\ ariefhapsoro@gmail.com \\ ${ }^{2}$ Universitas Telkom, Program Studi Desain Interior \\ kresensiabangun@gmail.com
}

\begin{abstract}
Sustainable development is a human effort to improve the quality of life by still striving not to exceed its life-sustaining ecosystem. Sustainable development can not be dissociable from the three aspects that also become the three main pillars, namely the economy, social, and the environment. Sustainable development was first introduced as a social destination at the first United Nations conference in the Environment in Stocklom in 1972. The backdrop of the conference was triggered by a global concern for protracted poverty and increased social injustice, coupled with food demand and global environmental issues and the realization that availability natural resources to support economic development are limited. The methods used in this study use quantitative methods. The methods used in this study use quantitative methods. In Indonesia, the concept of sustainable development also continues to develop and increase over time to solve problems in the country, such as poverty, education, environment, and health issues. The Government also took an important role in resolving the existing problems and the development process of sustainable development.
\end{abstract}

Keywords: Sustainable development, economics, Government, poverty

\begin{abstract}
Abstrak : Pembangunan berkelanjutan adalah upaya manusia untuk memperbaiki mutu kehidupan dengan tetap berusaha tidak melampaui ekosistem pendukung kehidupannya. Pembangunan berkelanjutan tidak dapat terlepasdari tiga aspek yang juga menjadi tiga pilar utamanya, yaitu ekonomi, social, dan lingkungan. Pembangunan Berkelanjutan pertama kali diperkenalkan sebagai tujuan sosial pada konferensi pertama PBB dalam bidang Lingkungan Hidup di Stocklom pada tahun 1972. Latar belakang diadakan konferensi tersebut dipicu oleh kekhawatiran global akan kemiskinan yang berlarut-larut dan meningkatnya ketidakadilan sosial, ditambah dengan kebutuhan pangan dan masalah lingkungan global serta kesadaran bahwa ketersedian sumber daya alam untuk mendukung pembangunan ekonomi amatlah terbatas. Metode yang digunakan dalam penelitian ini menggunakan metode Kuantitatif. Metode yang digunakan dalam penelitian ini menggunakan metode Kuantitatif.Di Indonesia sendiri konsep pembangunan berkelanjutan juga terus mengalami perkembangan dan peningkatan dari waktu ke waktu untuk menyelesaikan permasalahan yang ada di Negara ini, seperti masalah kemiskinan, pendidikan, lingkungan, dan kesehatan. Pemerintah juga mengambil peranan penting dalam menyelesaikan permasalahan yang ada dinegara ini serta proses pengembangan pembangunan berkelanjutan.
\end{abstract}

Kata Kunci : pembangunan berkelanjutan, ekonomi, pemerintah, kemiskinan

\section{PENDAHULUAN}

Pembangunan berkelanjutan mencakup tiga aspek, yaitu pembangunan ekonomi, pembangunan sosial dan perlindungan lingkungan. Ketiga aspek tersebut tidak bisa dipisahkan satu sama lain, karena ketiganya menimbulkan hubungan sebab-akibat. Aspek yang satu akan mengakibatkan aspek yang lainnya terpengaruh. Hubungan antara ekonomi dan sosial diharapkan dapat menciptakan hubungan yang adil (equitable). Hubungan antara ekonomi dan lingkungan diharapkan dapat terus berjalan (viable). Sedangkan hubungan antara sosial dan lingkungan bertujuan agar dapat terus bertahan (bearable). Ketiga aspek yaitu aspek ekonomi, sosial dan lingkungan akan menciptakan kondisi berkelanjutan (sustainable).

Konsep pembangunan berkelanjutan merupakan pembangunan berwawasan jangka panjang, yang meliputi jangka waktu antargenerasi dan berupaya menyediakan sumber daya yang cukup dan lingkungan yang sehat 
sehingga dapat mendukung kehidupan. Kemunculan konsep ini berkaitan erat dengan kesadaran tentang tatanan sosial dalam kehidupan bermasyarakat, dengan inti pada kepentingan ekonomi. Di Indonesia, pelaksanaan pembangunan yang berkelanjutan sudah mulai merambah dan dijadikan acuan pembangunan di segala bidang.

Pembangunan berkelanjutan erat kaitannya dengan aspek ekonomi untuk meningkatkan pertumbuhan ekonomi, terutama dalam penanganan kemiskinan, sebab saat ini di Indonesia kemiskinan menjadi fokus utama dalam perbaikan kondisi ekonomi masyarakat. Banyak sekali kebijakan pemerintah yang dilakukan untuk mencapai tujuan tersebut, khususnya untuk menurunkan tingkat kemiskinan. Sehingga, pembangunan berkelanjutan dapat menjadi salah satu solusi dari permasalahan yang ada di Indonesia saat ini.

Secara umum, keberlanjutan diartikan sebagai continuing without lessening, yang berarti melanjutkan aktivitas tanpa mengurangi. Pembangunan berkelanjutan sering menjadikonsep yang elusive, walaupun sudah menjadi jargon pembangunan di seluruh dunia (Fauzi, 2007:81).

Beberapa pengertian pembangunan berkelanjutan menurut para ahli:

a. Emil Salim (1990), bertujuan meningkatkan kesejahteraan masyarakat, untuk memenuhi kebutuhan dan aspirasi manusia. Pembangunan yang berkelanjutan pada hakikatnya ditujukan untuk mencari pemerataan pembangunan antargenerasi di masa kini maupun masa mendatang.

b. KLH (1990)pembangunan, yang pada dasarnya lebih berorientasi ekonomi, dapat diukur keberlanjutannya berdasarkan tiga kriteria, yaitu:

- Tidak ada pemborosan penggunaan sumber daya alam atau depletion of natural resources

- Tidak ada polusi dan dampak lingkungan lainnya

- Kegiatannya harus dapat meningkatkan useable resources ataupun replaceable resource.

c. Menurut Heal, (Fauzi, 2004). Konsep keberlanjutan ini paling tidak mengandung dua dimensi.
- dimensi waktu karena keberlanjutan tidak lain menyangkut apa yang akan terjadi di masa mendatang

- dimensi interaksi antara sistem ekonomi dan sistem sumber daya alam dan lingkungan

Pembangunan berkelanjutan memiliki tiga pilar utama yang saling berkesinambungan, diantaranya:

1. Pertumbuhan ekonomi, yakni menjaga pertumbuhan ekonomi yang stabil dengan merestrukturisasi sistem produktif untuk menghemat sumber daya dan energi.

2. Keberlanjutan sosial, yakni menjamin keadilan sosial dalam distribusi kekayaan dan pelayanan sosial.

3. Keberlanjutan lingkungan, yakni dengan menjaga lingkungan tempat tinggal agar nyaman dan aman melalui zero emission.

\section{METODOLOGI}

Metode yang digunakan dalam penulisan ini adalah metode penelitian deskriptif. Menurut Arikunto deskriptif adalah Penelitian yang dimaksudkan untuk menyelidiki keadaan, kondisi atau hal lain-lain yang sudah disebutkan, yang hasilnya dipaparkan dalam bentuk laporan penelitian. Dalam penelitian, peneliti tidak mengubah, menambah, atau mengadakan manipulasi terhadap objek atau wilayah penelitian.

Menurut Metode yang digunakan dalam penulisan ini adalah metode penelitian deskriptif. Menurut Arikunto deskriptif adalah Penelitian yang dimaksudkan untuk menyelidiki keadaan, kondisi atau hal lain-lain yang sudah disebutkan, yang hasilnya dipaparkan dalam bentuk laporan penelitian. Dalam penelitian, peneliti tidak mengubah, menambah, atau mengadakan manipulasi terhadap objek atau wilayah penelitian

\section{HASIL DAN PEMBAHASAN}

\section{Sejarah Perkembangan Pembangunan Berkelanjutan}

Konsep Sustainable Development atau Pembangunan Berkelanjutan pertama kali diperkenalkan sebagai tujuan sosial pada konferensi pertama PBB dalam bidang Lingkungan Hidup di Stocklom pada tahun 1972. Latar belakang diadakan konferensi tersebut dipicu oleh kekhawatiran global akan kemiskinan yang berlarut-larut dan meningkatnya 
ketidakadilan sosial, ditambah dengan kebutuhan pangan dan masalah lingkungan global serta kesadaran bahwa ketersedian sumber daya alam untuk mendukung pembangunan ekonomi amatlah terbatas.

Laporan Komisi Brundtland tahun 1987, menyebutkan bahwa Pembangunan Berkelanjutan merupakan sebuah pembangunan yang memenuhi kebutuhan di masa kini tanpa mengorbankan kemampuan generasi di masa depan untuk memenuhi kebutuhan mereka sendiri.

Berdasarkan pada Laporan tersebut, prinsip-prinsip dasar dari Pembangunan Berkelanjutan dapat dikategorikan sebagai berikut:

- Kepercayaan Publik/Masyarakat: Terdapat kewajiban negara untuk mengelola sumber daya alam yang dipercayakan untuk keuntungan masyarakatnya.

- Prinsip Kehati-hatian: adanya tindakan untuk mencegah kerusakan ireversibel atau kerusakan yang tidak dapat dipulihkan kembali dan pencegahannya tidak dapat ditunda hanya karena keterbatasan pengetahuan akan ilmu ilmiah.

- Keadilan Antar Generasi: Genarasi di masa depan tidak boleh dirugikan atau mendapat dampak buruk karena keputusan yang dibuat pada masa sekarang.

- Asas Subsidiaritas: Keputusankeputusan harus dibuat atau dilakukan dengan mempertimbangkan keputusan atau masukan dari lembaga maupun pemangku kepentingan pada tingkat terendah yang sesuai kapasitasnya.

- Pencemar Membayar: Biaya kerusakan/terganggunya lingkungan harus ditanggung oleh pihak-pihak yang turut bertanggung jawab akan kerusakan/gangguan tersebut.

\section{Sejarah Perkembangan Pembangunan Berkelanjutan di Indonesia}

Konsep mengenai pembangunan berkelanjutan atau sustainable development baru dimasukkan dalam amandemen yang keempat yang ditetapkan pada tanggal 10 Agustus 2002. Dengan adanya pengaturan mengenai hak atas lingkungan sebagai hak asasi manusia dan dengan di adopsinya prinsip pembangunan berkelanjutan (sustainable development) dan berwawasan lingkungan dalam UUD 1945 menjadikan konstitusi kita sudah bernuansa hijau (green constitution). Istilah Green Constitution ini dapat kita lihat dalam Pasal 28 huruf A UUD 1945 yang menyatakan bahwa "Setiap orang berhak untuk hidup serta berhak mempertahankan hidup dan kehidupannya" dan Pasal 33 ayat (4) UUD 1945 yang menyatakan bahwa:

Perekonomian nasional diselenggarakan berdasar atas demokrasi ekonomi dengan prinsip kebersamaan, efisiensi berkeadilan, berkelanjutan, berwawasan lingkungan, kemandirian, serta dengan menjaga keseimbangan kemajuan dan kesatuan ekonomi nasional.

Secara konsep, pembangunan di Indonesia dimulai sejak tahun 1969 (Repelita), yang tidak dapat dilepaskan dari kebijakan ekonomi baru di Indonesia yang terkait dengan permodalan, khususnya modal asing. Dalam Repelita yang pertama ini, aspek lingkungan yang terkait dengan pembangunan berkelanjutan belum masuk dalam konsep pembangunan pada saat itu,

Pengaruh dari konsep sustainable development juga berlanjut pada tahun 1982, yaitu dengan diberlakukannya Undang-Undang Nomor 4 Tahun 1982 tentang KetentuanKetentuan Pokok Pengelolaan Lingkungan Hidup (UUPLH 1982) dan dilanjutkan dengan diberlakukannya Undang-Undang Nomor 23 Tahun 1997 Tentang Pengelolaan Lingkungan Hidup (UUPLH 1997). Baik UUPLH 1982 maupun UUPLH 1997 pada dasarnya memiliki asas dan sasaran yang sama. Yang membedakan antara UUPLH 1982 dengan UUPLH 1997 yaitu karena adanya perkembangan di dunia.

Pengelolaan lingkungan hidup yang diselenggarakan dengan asas tanggung jawab negara, asas berkelanjutan, dan asas manfaat bertujuan untuk mewujudkan pembangunan berkelanjutan yang berwawasan lingkungan hidup dalam rangka pembangunan manusia Indonesia seutuhnya dan pembangunan masyarakat Indonesia seluruhnya yang beriman dan bertaqwa kepada Tuhan Yang Maha Esa.

Ketiga prinsip di atas, yaitu prinsip tanggung jawab negara (state responsibility), prinsip pembangunan berkelanjutan (sustainable development), prinsip manfaat dengan tujuan mewujudkan pembangunan berkelanjutan yang berwawasan lingkungan saling terkait erat dan mencerminkan kepentingan-kepentingan yang terpadu (holistic) dalam berbagai dimensi. 


\section{Pembangunan Berkelanjutan Berdasarkan Aspek Ekonomi}

Pembangunan berkelanjutan jelas mensyaratkan pertumbuhan ekonomi di tempat yang kebutuhan utamanya belum bisa konsisten dengan pertumbuhan ekonomi, asalkan isi pertumbuhan mencerminkan prinsip-prinsip keberlanjutan. Akan tetapi kenyataannya aktivitas produksi tinggi dapat saja terjadi bersamaan dengan kemelaratan yang tersebar luas. Kondisi ini dapat membahayakan lingkungan. Jadi pembangunan berkelanjutan mensyaratkan masyarakat terpenuhi kebutuahan dengan cara meningkatkan potensi produksi mereka dan sekaligus menjamin kesempatan yang sama semua orang.

Dari sisi ekonomi Fauzi (2004), setidaknya ada tiga alasan utama (faktor) mengapa pembangunan ekonomi harus berkelanjutan, yaitu:

a. Moral

Generasi kini menikmati barang dan jasa yang dihasilkan dari sumber daya alam dan lingkungan, sehingga secara moral perlu untuk memerhatikan ketersediaan sumber daya alam tersebut untuk generasi mendatang.

b. Ekologi

Keanekaragaman

hayati misalnya, memiliki nilai ekologi yang sangat tinggi, oleh karena itu aktivitas ekonomi semestinya tidak diarahkan pada kegiatan pemanfaatan sumber daya alam dan lingkungan semata yang pada akhirnya dapat mengancam fungsi ekologi.

c. Ekonomi

dimensi ekonomi berkelanjutan sendiri cukup kompleks, sehingga sering aspek keberlanjutan dari sisi ekonomi ini hanya dibatasi pada pengukuran kesejahteraan

antargenerasi(intergeneration welfare maximization).

Pada dasarnya sumber daya alam dan lingkungan memiliki kapasitas daya dukung yang terbatas. Dengan kata lain, pembangunan ekonomi yang tidak memerhatikan kapasitas sumber daya alam dan lingkungan akan menyebabkan permasalahan pembangunan di kemudian hari. Dalam mencapai pembangunan berkelanjutan dari perspektif ekonomi, maka manusaia harus mencari cara untuk memajukan ekonomi dalam jangka panjang, tanpa menghabiskan modal alam. Tiga elemen utama yang mendukung keberlanjutan ekonomi adalah kesejahteraan ekonomi yang berkesinambungan, pemerataan dan distribusi kemakmuran.

\section{Upaya Yang Dilakukan Pemerintah Dalam Mendukung Berkembangnya Pembangunan Berkelanjutan Dari Aspek Ekonomi Di Indonesia}

Pemerintah selalu mengupayakan berbagai cara untuk mensejahterakan rakyatnya dan untuk menanggulangi berbagai permasalahan yang ada di Negara ini. Pemerintahpun bereran aktif dalam mendukung berkembangnya pembangunan berkelanjutan dari aspek ekonomi di Indonesia. Beberapa upaya yang sudah di lakukan oleh pemerintah antara lain:

\section{a. Penanggulangan Kemiskinan Berbasis Pemberdayaan Komite Sekolah Menuju Pembangunan Berkelanjutan \\ KTT Pembangunan Berkelanjutandi Rio} de Jeneiro pada tahun 2012 (Rio+20) juga menghasilkan dokumen "The Future We Want" yang mencantumkan Sustainable Development Goals (SDGs) dan agenda pembangunan pasca2015 sebagai agenda sidang. Salah satu isu penting yang dibahas adalah pemberantasan kemiskinan sebagai tantangan terbesar yang dihadapi dunia saat ini dan syarat mutlak bagi pembangunan berkelanjutan

Pemerintah menindaklanjuti kesepakatan tersebut dengan pengarustamaan pembangunan berkelanjutan ke dalam Rencana Pembangunan Jangka Menegah Nasional (RPJMN). Salah satu agenda RPJMN 2015-2019 adalah pembangunan Indonesia dari pinggiran dengan memperkuat daerah dan desa-desa melalui peletakan dasar dimulainya desentralisasi asimetris, pemerataan pembangunan antar-wilayah terutama kawasan Indonesia timur, dan penanggulangan kemiskinan.

Data BPS menunjukkan terjadinya peningkatan angka kemiskinan sebesar 3,95 juta orang sepanjang tahun 2005 sampai 2006. Beberapa pengamat berpendapat bahwa selama ini program-program penanggulangan kemiskinan yang ada masih sebatas pemberian bantuan sosial, misalnya penyediaan beras bersubsidi untuk masyarakat miskin (raskin) dan Bantuan Langsung Tunai (BLT). Dalam jangka panjang, bantuan yang bersifat charity akan menimbulkan ketergantungan sehingga ketika program bantuan sosial telah selesai, tidak ada keberlanjutan program. Oleh karena itu, 
diperlukan upaya perubahan secara menyeluruh dalam penanggulangan kemiskinan. Pemberdayaan muncul sebagai solusi alternatif dalam penanggulangan kemiskinan. Pemberdayaan bisa dilakukan melalui berbagai bidang seperti pendidikan, lingkungan, kesehatan. Pemberdayaan pendidikan dapat direalisasikan melalui pembentukan Komite Sekolah yang mewakili orang tua murid sebagai patner sekolah dalam penyelenggaraan pendidikan sehingga dapat selaras dengan kebutuhan dan perkembangan masyarakat. Salah satu penanggulangan kemiskinan dapat melalui pemberdayaan dalam pendidikan karena penanggulangan kemiskinan dapat dimulai dari peningkatan kualitas individu yang lebih mengetahui persoalan dan potensi yang ada di masyarakat sehingga keputusan untuk memilih alternatif solusi dari masalah yang dihadapi ada dalam diri masing-masing individu dan dapat diwujudkan dalam bentuk partisipasi.

$$
\text { Masyarakat yang dilibatkan }
$$

sebagai subjek pendidikan akan mempunyai kesempatan untuk mengembangkan dan memberdayakan diri sehingga menumbuhkan kesadaran masyarakat akan pentingnya pendidikan untuk keluar dari berbagai permasalahan hidup termasuk kemiskinan.

Berlakunya Undang-Undang Otonomi Daerah akan mengubah pengelolaan pendidikan dari sentralistik menjadi desentralistik. Desentralisasi pendidikan memberikan kewenangan yang lebih luas kepada daerah untuk membuat perencanaan dan membuat keputusan atas permasalahan yang dihadapi di bidang pendidikan.

Dasar hukum pembentukan Komite Sekolah adalah UndangUndang Nomor 25 Tahun 2000 tentang Program Pembangunan Nasional 2000-2004 yang menyatakan bahwa dalam rangka pemberdayaan dan peningkatan peran serta masyarakat maka perlu dibentuk Dewan Pendidikan di tingkat kabupaten/kota dan provinsi serta Komite Sekolah di tingkat satuan pendidikan.

Tujuan dibentuknya Komite Sekolah untuk mewadahi dan menyalurkan aspirasi serta prakarsa masyarakat dalam melahirkan kebijakan operasional dan program pendidikan di satuan pendidikan, meningkatkan tanggung jawab dan peran serta masyarakat dalam penyelenggaraan pendidikan di satuan pendidikan serta menciptakan suasana dan kondisi transparan, akuntabel, dan demokratis dalam penyelenggaraan dan pelayanan pendidikan yang bermutu di satuan pendidikan. Keanggotaan Komite Sekolah berasal dari unsur-unsur yang ada dalam masyarakat seperti orang tua/wali peserta didik, tokoh masyarakat, tokoh pendidikan, dunia usaha, organisasi profesi pendidikan, wakil alumni, dan wakil peserta didik serta dewan guru, lembaga penyelenggara dan Badan Pertimbangan Desa.

Pendidikan akan berjalan sesuai prinsip demokrasi, di mana sekolah, orang tua peserta didik, dan masyarakat dapat berpartisipasi dan bertanggung jawab atas penyelenggaraan pendidikan di sekolah. Namun dalam implementasi, Komite Sekolah belum dapat menjalankan perannya secara optimal. Seperti Beberapa kasus terkait Komite Sekolah antara lain: kasus dugaan korupsi dana alokasi khusus (DAK) sebesar Rp556 juta untuk merehabilitasi ruang kelas SDN Baros Mandiri 5 tahun anggaran 2012 serta konflik Komite Sekolah dengan pihak manajemen SMAN 70 Jakarta yang berakhir di Pengadilan Negeri Jakarta Selatan.

Melihat belum optimalnya peran Komite Sekolah, maka perlu strategi pemberdayaan Komite Sekolah berdasarkan teori yang dikemukakan oleh Pranarka dan Vidhyanika, yaitu pendekatan instruksi dilakukan melalui reorganisasi, restrukturisasi, dan revitalisasi sehingga terbangun kemandirian melalui organisasi. Lalu pendekatan stimulasi, yaitu Komite Sekolah dapat memberikan bantuan social (Direktorat Jenderal Pendidikan Dasar Kementerian Pendidikan dan Kebudayaan). Dan pendekatan pemberdayaan yang terakhir adalah sosialisasi, yang bertujuan untuk menghindari persepsi yang salah terhadap peran masingmasing dalam penyelenggaraan pendidikan dan dapat dilaksanakan dalam bentuk workshop, seminar dialog, dan media massa.

b. Pembangunan Berkelanjutan dan Penanggulangan Kemiskinan

Menurut Emil Salim, pembangunan berkelanjutan harus diarahkan pada pemberantasan kemiskinan (sasaran ekonomi), perimbangan: ekuiti sosial yang adil (sasaran sosial) dan kualitas tinggi, kehidupan lingkungan hidup (sasaran lingkungan). Sosok final dari konsep pembangunan berkelanjutan di Indonesia belum terlihat jelas meski berbagai konvensi internasional dan pertemuan-pertemuan besar diikuti dan disepakati. Namun demikian, secara garis besar proses pelaksanaan pembangunan berkelanjutan di Indonesia meliputi tindakantindakan di bidang kebijakan public. 
Krisis di Indonesia menyebabkan turunnya kapasitas pemerintah untuk melakukan proteksi lingkungan sehingga kemampuan pemerintah untuk melanjutkan pelayanan dasar pada masyarakat miskin juga berkurang.

Saat ini masalah kemiskinan merupakan masalah mendesak yang dihadapi di Indonesia. Yang paling terlihat jelas adalah kondisi jutaan penduduk yang tinggal di permukiman kumuh dan liar. Kondisi kekumuhan ini menunjukkan seriusnya permasalahan sosial ekonomi, politik, dan lingkungan yang bermuara pada kondisi kemiskinan. Kerusakan lingkungan hidup merupakan ancaman utama bagi proses pembangunan berkelanjutan dengan melihat tujuan dari pembangunan berkelanjutan yaitu mencapai masyarakat sejahtera (masyarakat berkelanjutan) dalam lingkungan hidup yang berkelanjutan.

Dalam beberapa tahun terakhir angka kemiskinan di Indonesia memperlihatkan penurunan yang signifikan. Pendekatan kemiskinan yang berkembang selama ini perlu dilengkapi dengan konsep keberfungsian sosial yang lebih menggunakan demokrasisosial.

Penanganan kemiskinan merupakan salah satu masalah pembangunan yang sangat kompleks dan mempunyai dimensi tantangan, baik di tingkat lokal, nasional maupun global. Oleh karenanya hal ini tidak bisa dilepaskan dari strategi nasional untuk mewujudkan pembangunan berkelanjutan di suatu Negara.

Strategi penanganan kemiskinan tidak akan berhasil apabila tidak diintegrasikan ke dalam kebijakan pembangunan berkelanjutan yang mampu mengubah pola konsumsi masyarakat dan cara-cara produksi yang tidak menunjang keberlanjutan SDA dan lingkungan hidup. Selama ini program-program pengentasan kemiskinan telah banyak dilakukan oleh pemerintah. Namun tidak sedikit yang hanya bersifat reaktif dan temporer, di mana tidak memiliki keberlanjutan untuk menyelesaikan masalah kemiskinan tersebut secara tuntas.

Upaya penanganan kemiskinan dalam konsep pembangunan berkelanjutan, pemerintah perlu lebih melibatkan warga miskin sebagai subjeknya. Hal ini diharapkan mampu membuat masyarakat menjadi lebih mandiri dan berinisiatif untuk melakukan program-program sendiri. Program penanggulangan kemiskinan juga harus memberikan solusi baru demi terjadinya kesinambungan secara meningkat dari waktu ke waktu. Salah satu yang harus dilihat adalah usaha mikro ekonomi yang merupakan usaha kecil yang ada banyak terdapat di kalangan masyarakat kecil atau pedesaan. Penanganan kemiskinan merupakan pekerjaan berat yang harus ditanggung oleh pemerintah.

c. Peran Sektor Pertanian dalam Pembangunan Berkelanjutan

Sektor pertanian mempunyai peranan yang sangat penting dalam perekonomian nasional. Kontribusi dominan sektor pertanian khususnya dalam pemantapan ketahanan pangan, pengentasan kemiskinan, penciptaan lapangan kerja, dan pemerataan pendapatan. Pertanian berkelanjutan (sustainable agriculture) merupakan implementasi dari konsep pembangunan berkelanjutan (sustainable development) di sektor pertanian.

Indonesia merupakan negara yang memiliki keunggulan komperatif (comparative adventage) untuk sektor pertanian yang menjadi modal fundamental bagi pertumbuhan ekonomi yang perlu didorong dan dikelola dengan baik. Pengembangan komoditi unggulan di sektor pertanian pada suatu daerah merupakan suatu strategi regional untuk memacu pertumbuhan ekonomi, sehingga memberikan efek pengganda (multiplier effect) pada sub sektor lainnya. Data BPS 1998 menunjukkan, secara nasional sektor pertanian tumbuh $0,22 \%$, saat kondisi perekonomian Indonesia mengalami penurunan hingga $13,68 \%$.

Sektor pertanian memiliki peran yang sangat penting dalam pembangunan berkelanjutan seperti dalam ketahanan pangan, penciptaan lapangan kerja, peningkatan pendapatan dan penanggulangan kemiskinan, peningkatan devisa, pertumbuhan ekonomi, dan kelestarian lingkungan hidup.

Sektor pertanian memiliki peran yang sangat penting dalam pembangunan berkelanjutan seperti dalam ketahanan pangan, penciptaan lapangan kerja, peningkatan pendapatan dan penanggulangan kemiskinan, peningkatan devisa, pertumbuhan ekonomi, dan kelestarian lingkungan hidup.

Peran sektor pertanian lain yang juga sangat penting adalah dalam meningkatkan pembangunan ekonomi daerah. Pada saat ini sumber daya ekonomi yang dimiliki dan siap didayagunakan untuk pembangunan ekonomi 
daerah adalah sumber daya agribisnis seperti sumber daya alam (lahan, air, keragaman hayati, agroklimat), sumber daya manusia di bidang agribisnis, dan teknologi di bidang agribisnis. Pembangunan agribisnis perlu dijadikan sebagai pilar pembangunan ekonomi wilayah.

Pembangunan agribisnis mempunyai potensi untuk dapat mencegah dan memperbaiki kemerosotan mutu lingkungan hidup melalui beberapa cara. Pertama, pembangunan agribisnis akan membuka kesempatan ekonomi yang luas di setiap daerah (ruang). Kedua, pembangunan agribisnis yang pada dasarnya mendayagunakan keragaman hayati, dapat mempertahankan keberadaan keanekaragaman hayati. Ketiga, pembangunan agribisnis yang mendayagunakan pertumbuhan keragaman tumbuhan, yang merupakan "perkebunan karbon" yang efektif dalam mengurangi emisi gas karbon atmosfir. Keempat, pembangunan agribisnis akan menghasilkan produk yang bersfiat biodegradable yang dapat terurai secara alamiah. Kelima, pembangunan agribisnis yang bergerak dari factor-driven ke capital driven dan kemudian kepada innovation-driven dalam menghasilkan nilai tambah dapat mengurangi tekanan terhadap sumber daya alam dan lingkungan hidup.

Beberapa persoalan utama yang dihadapi sektor pertanian adalah: pertama, stagnasi produk pertanian. Dalam dua puluh tahun terakhir ini terjadi stagnasi produksi di hampir semua sektor tanaman pangan. Peningkatan produksi tahunan rata-rata di atas $4 \%$ sebagaimana tahun 1970 hingga 1980an tidak pernah lagi tercapai. Kedua, piramida struktur pertanian dan ketimpangan agrarian. Pola piramida struktur pertanian dan pangan yang ada saat ini mendudukkan agribisnis, produsen benih dan input pertanian, pertanian korporasi, pertanian kapitalistik, dan spekulen pangan di puncak piramida dengan jumlah kurang dari 500.000 orang. Sedangkan dasar piramida tersusun dari 26,13 juta keluarga petani kecil atau 91 juta jiwa. Puncak piramida tersebut menekan ke bawah dan menyebabkan 5 juta keluarga petani kecil tercerabut dari lahan mereka dalam 10 tahun terakhir. Selain itu ketersediaan lahan pangan per kapita juga sangat sempit. Untuk lahan sawah, per kapita penduduk Indonesia hanya memiliki $326,2 \mathrm{~m} 2$ , sedangkan lahan kering yang sebagian besar kurang produktif sebesar $568,7 \mathrm{~m} 2$, yang jauh lebih rendah dengan beberapa negara tetangga kita yaitu Vietnam (960 m2 ), Thailand (5226 $\mathrm{m} 2$ ), China (1120 m2 ), India (1591 m2 ), dan Australia (26.264 m2 ). Konversi lahan pertanian ke non-pertanian diperkirakan sebesar 60.000 hektar per tahun, yang terkompensasi sebagian dari perluasan lahan pertanian terutama di luar Jawa. Proses deagrarianisasi juga berlangsung pesat terutama di wilayah-wilayah pertanian luar Jawa yang berdekatan dengan kawasan pertambangan. Lahan-lahan pertanian terbengkalai atau dijual dan diubah menjadi kawasan pertambangan. Dengan demikian kesimpulan sementara yang diambil oleh pemerintah bahwa penurunan jumlah rumah tangga petani menyebabkan peningkatan luasan lahan yang dikuasai oleh rumah tangga petani dari 0,41 ha (2003) menjadi 0,89 ha (2013) adalah sangat menyesatkan.

Dengan memahami peran sektor pertanian dalam pembangunan berkelanjutan serta permasalahan yang ada, maka terdapat beberapa sejumlah agenda penting yang dapat dilakukan, yaitu:

- Demokratisasi Pertanian dan Kedaulatan Petani

Oleh pemerintah, DPR dan kalangan pengusaha. Hal tersebut menyebabkan banyak rencana kebijakan pertanian menjadi bermasalah bagi petani. Dalam kedaulatan pangan, petani kecil wajib dilibatkan dalam penetapan kebijakan pertanian baik di pusat maupun daerah. Dari berbagai diskusi dengan kelompokkelompok tani yang mandiri dan berdaulat, produktivitas pertanian mereka rata-rata $25 \%$ hingga $50 \%$ lebih tinggi dibanding petani lainnya. Produktivitas yang tinggi tersebut secara langsung berpengaruh terhadap peningkatan kesejahteraan mereka.

- Reforma Agraria

Saat ini diperlukan pengawalan terusmenerus pelaksanaan reforma agraria sehingga petani kecil dan tuan tanah memiliki akses terhadap lahan serta upaya terkait lainnya untuk meningkatkan kesejahteraan mereka. 
- Akses Petani Terhadap Sumber daya Produktif

Reforma agararia berkaitan juga dengan akses petani kecil terhadap sumber daya produktif yang meliputi air, sumber daya genetik dan sumber daya alam. Tiga hal tersebut sangat berpengaruh terhadap keberlanjutan usaha tani, hanya sayangnya akses ke sumber daya tersebut bukan semakin menguat tetapi semakin melemah.

\section{- Pertanian Agroekologi}

Sistem pertanian agroekologi menjadi dasar banyak gerakan petani kecil di seluruh dunia dan dijadikan penciri kedaulatan pangan yang sering direduksi menjadi pertanian organic. Agroekologi didefinisikan sebagai penerapan ilmu ekologi mengenai distribusi dan kelimpahan organisme di lingkungan pertanian untuk meningkatkan hasil pertanian dan melindungi tanaman dari serangan hama dan penyakit.

- Rasionalisme Hijau

Diskursus lingkungan untuk ketahanan pangan adalah rasionalisme ekonomi karena entitas utama dalam ketahanan pangan adalah aktor-aktor ekonomi. Hubungan antar-aktor adalah kompetisi dan motivasi aktor merupakan kebutuhan pribadi (rational self interest). Berkebalikan dengan hal tersebut adalah rasionalisme hijau. Kedaulatan pangan memproklamasikan pengakuan tentang kompleksitas produksi pangan, hubungan komunal antar- petani serta petani dengan alam dan penggunaan sistem produksi agroekologi.

\section{PENUTUP \\ Simpulan}

Pembangunan berkelanjutan mensyaratkan masyarakat terpenuhi kebutuahan dengan cara meningkatkan potensi produksi mereka dan sekaligus menjamin kesempatan yang sama semua orang. Dengan kata lain, pembangunan ekonomi yang tidak memerhatikan kapasitas sumber daya alam dan lingkungan akan menyebabkan permasalahan pembangunan di kemudian hari. Tiga elemen utama yang mendukung keberlanjutan ekonomi adalah kesejahteraan ekonomi yang berkesinambungan, pemerataan dan distribusi kemakmuran.
Salah satu isu penting yang dibahas dalam KTT Pembangunan Berkelanjutan di Rio de Jeneiro pada tahun 2012 (Rio+20) adalah pemberantasan kemiskinan sebagai tantangan terbesar yang dihadapi dunia saat ini dan syarat mutlak bagi pembangunan berkelanjutan. Data BPS menunjukkan terjadinya peningkatan angka kemiskinan sebesar 3,95 juta orang sepanjang tahun 2005 sampai 2006.

Pemberdayaan muncul sebagai solusi alternatif dalam penanggulangan kemiskinan. Salah satunya adalah pemberdayaan pendidikan yang dapat direalisasikan melalui pembentukan Komite Sekolah yang mewakili orang tua murid sebagai patner sekolah dalam penyelenggaraan pendidikan sehingga dapat selaras dengan kebutuhan dan perkembangan masyarakat.

Tujuan dibentuknya Komite Sekolah untuk mewadahi dan menyalurkan aspirasi serta prakarsa masyarakat dalam melahirkan kebijakan operasional dan program pendidikan di satuan pendidikan, meningkatkan tanggung jawab dan peran serta masyarakat dalam penyelenggaraan pendidikan serta menciptakan suasana dan kondisi transparan, akuntabel, dan demokratis dalam penyelenggaraan dan pelayanan pendidikan yang bermutu di satuan pendidikan. Pendidikan akan berjalan sesuai prinsip demokrasi, di mana sekolah, orang tua peserta didik, dan masyarakat dapat berpartisipasi dan bertanggung jawab atas penyelenggaraan pendidikan di sekolah.

Sosok final dari konsep pembangunan berkelanjutan di Indonesia belum terlihat jelas meski berbagai konvensi internasional dan pertemuan-pertemuan besar diikuti dan disepakati. Namun demikian, secara garis besar proses pelaksanaan pembangunan berkelanjutan di Indonesia meliputi tindakan-tindakan di bidang kebijakan public. Yang paling terlihat jelas adalah kondisi jutaan penduduk yang tinggal di permukiman kumuh dan liar.

Kondisi kekumuhan ini menunjukkan seriusnya permasalahan sosial ekonomi, politik, dan lingkungan yang bermuara pada kondisi kemiskinan. Penanganan kemiskinan merupakan salah satu masalah pembangunan yang sangat kompleks dan mempunyai dimensi tantangan, baik di tingkat lokal, nasional maupun global. Oleh karenanya hal ini tidak bisa dilepaskan dari strategi nasional untuk mewujudkan pembangunan berkelanjutan di suatu Negara.

Selama ini program-program pengentasan kemiskinan telah banyak dilakukan oleh pemerintah. Namun tidak sedikit yang hanya 
bersifat reaktif dan temporer, di mana tidak memiliki keberlanjutan untuk menyelesaikan masalah kemiskinan tersebut secara tuntas. Dari sektor pertanian, mempunyai peranan yang sangat penting dalam perekonomian nasional. Kontribusi dominan sektor pertanian khususnya dalam pemantapan ketahanan pangan, pengentasan kemiskinan, penciptaan lapangan kerja, dan pemerataan pendapatan. Indonesia merupakan negara yang memiliki keunggulan komperatif (comparative adventage) untuk sektor pertanian yang menjadi modal fundamental bagi pertumbuhan ekonomi yang perlu didorong dan dikelola dengan baik.

Dalam kedaulatan pangan, petani kecil wajib dilibatkan dalam penetapan kebijakan pertanian baik di pusat maupun daerah. Reforma agararia berkaitan juga dengan akses petani kecil terhadap sumber daya produktif yang meliputi air, sumber daya genetik dan sumber daya alam. Sistem pertanian agroekologi menjadi dasar banyak gerakan petani kecil di seluruh dunia dan dijadikan penciri kedaulatan pangan yang sering direduksi menjadi pertanian organic.

\section{DAFTAR PUSTAKA}

\section{Buku}

Susiana, Sali. (Ed). 2015. Pembangunan Berkelanjutan : Dimensi Sosial, Ekonomi, dan Lingkungan. Jakarta: P3DI Setjen DPR RI dan Azza Grafika

Departemen Pendidikan Nasional Direktorat Jenderal Manajemen Pendidikan Dasar dan Menengah. Pemberdayaan Dewan Pendidikan dan Komite Sekolah. Jakarta: Departemen Pendidikan Nasional Direktorat Jenderal Manajemen Pendidikan Dasar dan Menengah, 2007.

Santosa, D. A. Kedaulatan Petani Mengatasi Dampak Perubahan Iklim. Jakarta: Agrimedia, 2011.

\section{Media Elektronik}

Kemiskinan Di Indonesia. (http://www.indonesia-investments. com/id/keuangan/angka-ekonomimakro/kemiskinan/ item301, diakses 25 Agustus 2015)

Kepala SDN Baros Mandiri 5 dan Ketua Komite Jadi Tersangka Kasus DAK. (http://www.pikiranrakyat.com/bandungraya/2014/09/1 1/296520/kepala-sdn-baros-mandiri- 5-danketua-komite-jadi-tersangkakasus-dak, diakses 2 September 2015).

Program BLT Tak Menekan Angka Kemiskinan. (http://www. indosiar.com/fokus/program-blt-takmenekan-

angkakemiskinan_69766.html, diakses 25 Agustus 2015).

Raskin, Beras Bersubsidi Bagi Masyarakat Berpenghasilan Rendah. (http://www.tnp2k.go.id/id/tanyajawab/klaster-i/berasbersubsidi-bagimasyarakat-berpenghasilan-rendahraskin/, diakses 25 Agustus 2015).

\section{Peraturan Perundang-undangan}

Republik Indonesia. Keputusan Menteri Pendidikan Nasional Nomor 044/U/2002 tentang Dewan Pendidikan dan Komite Sekolah.

Republik Indonesia. Peraturan Pemerintah Nomor 39 Tahun 1992 tentang Peran Serta Masyarakat Dalam Pendidikan Nasional.

Republik Indonesia. Undang-Undang Nomor 20 Tahun 2003 tentang Sistem Pendidikan Nasional.

Republlik Indonesia. Undang-Undang Nomor 25 Tahun 2000 tentang Program Pembangunan Nasional 2000-2004.

"Kemiskinan di Indonesia". Lihat:http://www.indonesia-

investments. com/id/keuangan/angkaekonomi- makro/kemiskinan/item301, diakses tanggal 16 Juni 2015

\section{Jurnal}

Fauzi, Akhmad dan Alex Oxtavianus. 2014.Pengukuran Pembangunan Berkelanjutan di Indonesia, 30(1),43-33.

Friyatno, S. 2001. Analisis Penerapan Intensifikasi Usahatani Padi Sawah Pasca Krisis Ekonomi (Kasus di Kabupaten Subang, Jawa Barat). Makalah. Badan Penelitian dan Pengembangan Pertanian, Departemen Pertanian RI. 